The determination of some biochemical contents of Helichrysum armenium DC. subsp. araxinum (Kirp.) Takht

Muammer BAHŞI ${ }^{* 1}$, Mustafa Yunus EMRE 2 , İrfan EMRE ${ }^{1}$, Murat KURŞAT $^{3}$, Ökkeş YILMAZ

ORCID: 0000000155709509, 0000000166028872, 0000000305913397, 0000000208614213, 0000000282764498

${ }^{11}$ Firat University, Faculty of Education, Department of Primary Education, Elazig/ Turkey

${ }^{2}$ Mardin Artuklu University, Vocational School of Health Services, Mardin/ Turkey

${ }^{3}$ Bitlis Eren University, Faculty of Arts and Science, Department of Biology, Bitlis/ Turkey

${ }^{4}$ Firat University, Faculty of Science, Department of Biology, Elazig/ Turkey

\begin{abstract}
The aim of current study was to determine fatty acid compositions, lipid soluble vitamins, phenolic compounds, radical scavenging activities, antioxidant activity and metal chelating capacity of Helichrysum armenium subsp. araxinum extracts. It was found that palmitic acid (C16:0) was primary fatty acid (58,99 $\pm 1,21 \%)$. Current study demonstrated that lipid soluble vitamin contents were lowest. However, stigmasterol and $\beta$-sitosterol were found as 79,4 $\pm 1,17$ and $29,2 \pm 0,87$, respectively in this study. Also, present study showed that $H$. armenium subsp. araxinum has highest naringin content $(1156,8 \pm 3,57 \mu \mathrm{g} / \mathrm{g})$ whilst it has high vanillic acid $(213,2 \pm 2,32 \mu \mathrm{g} / \mathrm{g})$, caffeic acid $(151,6 \pm 1,27 \mu \mathrm{g} / \mathrm{g})$ and ferulic acid $(117,94 \pm 1,26 \mu \mathrm{g} / \mathrm{g})$ contents. On the other hand, it was demonstrated that $H$. armenium subsp. araxinum has highest DPPH (except for $10 \mu \mathrm{l}$ ), ABTS radical scavenging activities and metal chelating capacity in $100 \mu 1$.
\end{abstract}

Key words: fatty acids, Helichrysum armenium subsp. araxinum, lipid soluble vitamins, phenolics, radical scaveging activity

\title{
Helichrysum armenium DC. subsp. araxinum (Kirp.) Takht. taksonunun bazı biyokimyasal içeriklerinin belirlenmesi
}

\section{Özet}

Bu çalışmanın amacı, Helichrysum armenium subsp. araxinum özütlerinin yağ asidi bileşimi, yağda çözünen vitaminleri, fenolik bileşikleri, radikal temizleme faaliyetleri, antioksidan aktivitesi ve metal şelatlama kapasitesini belirlemektir. Araştırmada palmitik asidin (C16:0) birincil yağ asidi olduğu ve $(58,99 \pm 1,21 \%)$ yağda çözünen vitamin içerilerinin en düşük seviyede olduğunu belirlenmiştir. Stigmasterol ve $\beta$-sitosterol, sirasıyla 79,4 $\pm 1,17$ ve $29,2 \pm 0,87$ olarak tespit edilmiştir. Ayrıca mevcut çalışma, Helichrysum armenium subsp. araxinum'un en yüksek naringin içeriğine $(1156,8 \pm 3,57 \mu \mathrm{g} / \mathrm{g})$ sahip olduğunu ayrıca yüksek miktarda vanilik asit $(213,2 \pm 2,32 \mu \mathrm{g} / \mathrm{g}), \mathrm{kafeik}$ asit $(151,6 \pm 1,27$ $\mu \mathrm{g} / \mathrm{g})$ ve ferulik asit $(117,94 \pm 1,26 \mu \mathrm{g} / \mathrm{g})$ içeriğine sahip olduğunu göstermiştir. Öte yandan, Helichrysum armenium subsp. araxinum, en yüksek DPPH (10 $\mu$ l hariç $)$, ABTS radikal temizleme aktivitesi ve $100 \mu$ l'de metal şelatlama kapasitesine sahiptir.

Anahtar kelimeler: yağ asitleri, Helichrysum armenium subsp. araxinum, yağda çözünen vitaminler, fenolikler, radikal temizleme aktivitesi

\section{Introduction}

The name of Helichrysum, is composed of the combination of Greek words helios and chryos which meaning sun and gold because it has inflorescences of a shining yellow [1]. The genus is usually known as "Altın Otu" or "Ölmez

\footnotetext{
* Corresponding author / Haberleşmeden sorumlu yazar: Tel.: +905326078937; Fax.: +904242365064; E-mail: muammerbahsi@ @otmail.com

(C) Copyright 2020 by Biological Diversity and Conservation $\quad$ Received: 18.06.2019; Published: 15.04.2020 
Çiçek" in Turkey and used as herbal tea [2]. The genus comprises more than a thousand taxa which significantly spread out in the Mediterranean areas. Genus Helichrysum is naturally distributed in Turkey [3-6]. In Turkish flora, the genus is represented by 27 taxa, of which the endemism ratio is $55 \%$ [7]. The members of genus may be annuals, herbaceous perennials or shrubs, expanding to a height of $90 \mathrm{~cm}$ [8]. It grows on rocky, dry or sandy areas in the Mediterranean [9].

Species from Helichrysum generally are used traditional medicine against kidney stones, inflammation, gallbladder, cold, liver, diabetes and digestive disorders [10,11]. It has been approved by World Health Organization and European Medicines Agency consuming as the infusion or decocation of flowers of species from genus [12]. It is accepted that the curative effects of genus is chiefly due to some antioxidants including mainly flavonoids, coumarins, phenolic acids contents. Phenolics have significant role as antioxidant against lipid peroxidation [13]. Their antioxidant capacity is come from act as hydrogen donor, scavenging free superoxide cavenger and metal chelating [14]. The aim of present study is to determine the fatty acids, lipid soluble vitamins, sterols, phenolic contents, radical scavenging activities, metal chelating of Helichrysum armenium subsp. araxinum.

\section{Materials and methods}

\subsection{Chemical agents}

All chemicals were supplied from Sigma-Aldrich.

\subsection{Plant materials}

Sample plants were collected from Harput/Elazig and identified by Dr. Murat KURSAT in 2011 and were stored in the Firat University Herbarium. The fatty acid compositions, lipid soluble vitamins, flavonoids, phenolic acids radical scavenging activity (DPPH and ABTS), Fe chelating were evaluated in the Helichrysum armenium subsp. araxinum extracts. Experiments were repeated three times.

\subsection{The analysis of fatty acid, lipid soluble vitamins and sterol}

$2 \mathrm{~g}$ seed materials finely ground in a mill and were extracted with isopropanol/hexane $(2: 3 \mathrm{v} / \mathrm{v})$ for fatty acid, sterol and vitamin analyses were [15]. The lipid extracts were centrifuged at $10.000 \mathrm{~g}$ for 5 minutes and filtered. The solvent was then removed by using rotary evaporator at $40^{\circ} \mathrm{C}$. The samples were kept at $-25^{\circ} \mathrm{C}$. The experiment was repeated three times.

\subsubsection{The analysis of fatty acids}

$2 \%$ sulphuric acid (v/v) in methanol was used to form fatty acid methyl esters [16]. The fatty acid methyl esters were treated with n-hexane and separated by gas chromatography and flame-ionization detection (Shimadzu GC 17 Ver.3) coupled to a Glass GC 10 software. Nitrogen was used as carrier gas flow ratio $0.8 \mathrm{ml} / \mathrm{min}$. and capillary column ( $25 \mathrm{~m}$ in length and $0.25 \mathrm{~mm}$ in diameter; Permabound 25, Macherey-Nagel, Germany) was used to conduct the chromatographic analysis. The heat of, detector, column and injection valve were adjusted as $240,130-220$, and $280^{\circ} \mathrm{C}$, respectively.

\subsubsection{Chromatographic analysis and quantification of lipid soluble vitamins and sterols}

Lipid-soluble vitamins and phytosterols were taken from the lipid fraction based on the method of SánchezMachado [17]. The samples were dissolved in acetonitrile/methanol (75/25 v/v) and $50 \mathrm{~mL}$ were injected into the HPLC (Shimadzu, Japan). A Supelcosil TM LC18 (250 x $4.6 \mathrm{~mm}, 5 \mathrm{~mm}$, Sigma, USA) was used as column and acetonitrile/methanol $(75 / 25, \mathrm{v} / \mathrm{v})$ was used as mobile phase. The temperature of the column was kept at $40^{\circ} \mathrm{C}$. Determination was performed at $320 \mathrm{~nm}$ for retinol (vitamin A) and retinol acetate, and $215 \mathrm{~nm}$ for d-tocopherol, vitamin D, a-tocopherol, a-tocopherol acetate, $202 \mathrm{~nm}$ for phytosterols, $265 \mathrm{~nm}$ for vitamin K1 [18]. Class Vp 6.1 software was used to obtain data. The results of the analyses were written as $\mu \mathrm{g} / \mathrm{g}$ for samples.

\subsection{Extraction of seed materials for phenolics}

Homogenisation was conducted by using $5 \mathrm{ml} 80 \%$ methanol to measure the flavonoid and phenolic acids. The samples were centrifuged at $5000 \mathrm{rpm}$ at $+4^{\circ} \mathrm{C}$ and dimethyl sulphoxide (DMSO) was used to provide a reserve solution.

\subsection{Chromatographic conditions for flavonoids}

Chromatographic analysis was done method offered by $\mathrm{Zu}$ et al. [19]. Column was PREVAIL C18 reversedphase column $(15 \times 4.6 \mathrm{~mm}, 5 \mu \mathrm{m}$, USA) and mobile phase was methanol /water/acetonitrile $(46 / 46 / 8$, v/v/v) comprisng $1.0 \%$ acetic acid [19]. It was used $1.0 \mathrm{ml} / \mathrm{min}$. as flow ratio and chromatographic peaks were confirmed by determining 
retention times with those of the standards. Resveratrol, quercetin, naringenin, naringin, catechin, myricetin, morin, rutin, kaempferol and vanillic acid, cinnamic acid, caffeic acid, ferulic acid and rosmarinic acid were measured by DAD following RP-HPLC. Flow ratio were $1.0 \mathrm{ml} / \mathrm{min}$ and the chromatographic peaks of the samples were affirmed by measuring retention times with those of the standards. Chromatographic studies were done at $25^{\circ} \mathrm{C}$.

\subsection{Antioxidant activity}

\subsubsection{DPPH radical scavenging capacity}

DPPH radical was afresh prepared based on method by Liyana- Pathiranan and Shahidi (2005). 4. $0 \mathrm{ml}$ DPPH solution were mixed with $25,50,100,150$ and $250 \mu \mathrm{L}$ of extract. The complex were kept at the dark for 30 minutes at room temperature. The absorbances were measured spectrophometrically at $517 \mathrm{~nm} .1 \mu \mathrm{M}$ quercetin was used as reference [20]. The results were determined by using formula:

DPPH radical scavenging capacity $(\%)=[($ Abs_control - Abs_sample $)] /($ Abs control $)] \times 100$

Abs_control is the absorbance of DPPH radical + methanol; Abs_sample is the absorbance of DPPH radical + sample extract/standard.

\subsubsection{ABTS 2,2-azinobis-(3-ethylbenzothiazoline-6-sulfonic acid) diammonium salt assay}

ABTS radical cation assay was defined method done by Ree et al. [21]. The ABTS radical cation (ABTS•+) and $7 \mathrm{mM}$ ABTS mixed with $2.45 \mathrm{mM}$ potassium persulphate to obtain ABTS radical cation. The solution kepted for $12-16$ $\mathrm{h}$ at room temperature. The $\left(\mathrm{ABTS}^{\bullet^{+}}\right)$solution was dissolved with water to measure an absorbance of $0.700 \pm 0.020$ at $734 \mathrm{~nm} .3 \mathrm{ml}$ ABTS solution were mixed with 25, 50, 100, 150 and $250 \mu \mathrm{L}$ of extract and absorption was detected during 6 min. Absorbance of control $(3.0 \mathrm{~mL}(\mathrm{ABTS} \bullet+)$ solution with $30 \mathrm{~L}$ water) was written as Acontrol [22].

ABTS radical cation scavenging capacity $(\%)=[($ Abs_control - Abs_sample $)] /($ Abs_control) $] \times 100$

\subsubsection{Metal chelating activity}

The chelating capacity were done method by Dinis et al. [23]. $50 \mu$ of $2 \mathrm{mM} \mathrm{FeCl}_{2}$ was added to several concentrations including $50,100,250$ and $500 \mu \mathrm{g} / \mathrm{mL}$ of extracts. $5 \mathrm{mM}$ ferrozine $(0.2 \mathrm{~mL})$ added to mixture to start reaction. The solution kept at the room temperature for 10 minutes after the solutions was mixed strongly. $562 \mathrm{~nm}$ was used as abosrbance [23]. The percentage inhibiting of of ferrozine-- $\mathrm{Fe}^{2+}$ complex was found following formula:

Ferrous ion chelating activity $(\%)=[1-(\mathrm{As} / \mathrm{Ac})] \times 100$ where $\mathrm{A}_{\mathrm{c}}$ was the absorbance of the control, and As was the absorbance of the extract/ standard [24]. Positive control was $\mathrm{Na}_{2}$ EDTA.

\section{Results}

Table 1. Fatty acid compositions of Helichrysum armenium subsp. araxinum

\begin{tabular}{|c|c|}
\hline Fatty Acids & $\begin{array}{c}\text { Fatty acid } \\
\text { composition \% }\end{array}$ \\
\hline $\mathbf{1 0 : 0}$ & $1,88 \pm 0,27$ \\
\hline $\mathbf{1 4 : 0}$ & $2,72 \pm 0,32$ \\
\hline $\mathbf{1 6 : 0}$ & $58,99 \pm 1,21$ \\
\hline $\mathbf{1 6 : 1 ~ n 7}$ & $4,73 \pm 0,33$ \\
\hline $\mathbf{1 8 : 0}$ & $5,47 \pm 0,74$ \\
\hline $\mathbf{1 8 : 1}$ n9 & $9,20 \pm 0,84$ \\
\hline $\mathbf{1 8 : 2}$ n6c & $5,57 \pm 0,68$ \\
\hline $\mathbf{1 8 : 3 n 3}$ & $2,65 \pm 0,2$ \\
\hline $\mathbf{2 4 : 1}$ & $8,74 \pm 0,79$ \\
\hline
\end{tabular}

Present study showed that Helichrysum armenium subsp. araxinum has highest palmitic acid content (C16:0; $8,99 \pm 1,21 \%)$. The other saturated fatty acids were stearic acid (C18:0; 5,47 $\pm 0,74 \%)$, capric acid $(\mathrm{C} 10: 0 ; 1,88 \pm 0,27 \%)$ and myristic acid $(\mathrm{C} 14: 0 ; 2,72 \pm 0,32 \%)$. On the other hand, oleic acid $(18: 1 \mathrm{n} 9 ; 9,20 \pm 0,84 \%)$, linoleic (C18:2 n 6; $5,57 \pm 0,68)$, linolenic acids (C18:3 n $3 ; 2,65 \pm 0,2)$ and nervonic acid (C:24:1; 8,74 $\pm 0,79 \%$ ) were found as unsaturated fatty acids.

Table 2. Lipid soluble vitamin and sterol contents of Helichrysum armenium subsp. araxinum

\begin{tabular}{|c|c|}
\hline Lipid-soluble vitamins & Amounts $(\boldsymbol{\mu g} / \mathbf{g})$ \\
\hline K1 & $0,1 \pm 0,01$ \\
\hline K2 & $0,1 \pm 0,01$ \\
\hline R-tocopherol & $0,4 \pm 0,01$ \\
\hline D2 & $0,3 \pm 0,01$ \\
\hline D3 & $0,05 \pm 0,01$ \\
\hline a-tocopherol & $4,5 \pm 0,57$ \\
\hline Ergosterol & $0,5 \pm 0,01$ \\
\hline Stigmasterol & $79,4 \pm 1,17$ \\
\hline B-sitosterol & $29,2 \pm 0,87$ \\
\hline
\end{tabular}


It was found that lipid soluble vitamin and ergosterol contents of Helichyrsum were lowest or trace amounts. However, stigmasterol $(79,4 \pm 1,17 \mu \mathrm{g} / \mathrm{g})$ and $\beta$-sitosterol $(29,2 \pm 0,87 \mu \mathrm{g} / \mathrm{g})$ contents of Helichrysum armenium subsp. araxinum were relatively high.

Table 3. Flavanoid contents of Helichrysum armenium subsp. araxinum

\begin{tabular}{|c|c|}
\hline Flavonoids & Amounts $(\boldsymbol{\mu g} / \mathbf{g})$ \\
\hline Rutin & $396,24 \pm 2,57$ \\
\hline Myricetin & $18,8 \pm 0,59$ \\
\hline Morin & $1,1 \pm 0,04$ \\
\hline Quercetin & $0,2 \pm 0,01$ \\
\hline Kaempherol & - \\
\hline Catechin & $181,8 \pm 2,47$ \\
\hline Naringin & - \\
\hline Naringenin & $1156,8 \pm 3,57$ \\
\hline Resveratrol & - \\
\hline
\end{tabular}

Present study showed that quercetin, kaempherol, naringenin and resveratrol contents of Helichyrsum were lowest or absent. However, the naringin amount of Helichyrsum armenium subsp. araxinum was found highest $(1156,8 \pm 3,57 \mu \mathrm{g} / \mathrm{g})$. Also, it was found that rutin $(396,24 \pm 2,57 \mu \mathrm{g} / \mathrm{g})$ and catechin $(181,8 \pm 2,47 \mu \mathrm{g} / \mathrm{g})$ amounts of Helichyrsum armenium subsp. araxinum were high. The myricetin content of Helichyrsum armenium subsp. araxinum was determined as $18,8 \pm 0,59 \mu \mathrm{g} / \mathrm{g}$.

Table 4. Phenolic acid contents of Helichrysum armenium subsp. araxinum

\begin{tabular}{|c|c|}
\hline Phenolic acids & Amount $(\boldsymbol{\mu g} \mathbf{g} \mathbf{g})$ \\
\hline Vanillic acid & $213,2 \pm 2,32$ \\
\hline Cinnamic acid & $7,1 \pm 0,84$ \\
\hline Caffeic acid & $151,6 \pm 1,27$ \\
\hline Ferulic acid & $117,94 \pm 1,26$ \\
\hline Rosmarinic acid & $26,6 \pm 0,87$ \\
\hline
\end{tabular}

It was found that Helichyrsum has low cinnamic acid $(7,1 \pm 0,84 \mu \mathrm{g} / \mathrm{g})$ and rosmarinic acid contents $(26,6 \pm 0,87$ $\mu \mathrm{g} / \mathrm{g})$. However, it has high vanillic acid $(213,2 \pm 2,32 \mu \mathrm{g} / \mathrm{g})$, caffeic acid $(151,6 \pm 1,27 \mu \mathrm{g} / \mathrm{g})$ and ferulic acid $(117,94 \pm 1,26$ $\mu \mathrm{g} / \mathrm{g})$ contents.

Table 5. DPPH and ABTS radical scavenging activities of Helichrysum armenium subsp. araxinum

\begin{tabular}{|c|c|c|}
\hline Concentrations & DPPH \% & ABTS \% \\
\hline $\mathbf{1 0} \boldsymbol{\mu l}$ & $36,1 \pm 0,97$ & $98,1 \pm 1,11$ \\
\hline $\mathbf{2 5} \boldsymbol{\mu l}$ & $69,6 \pm 0,74$ & $99,48 \pm 1,21$ \\
\hline $\mathbf{5 0} \boldsymbol{\mu l}$ & $92,4 \pm 1,1$ & $98,62 \pm 0,97$ \\
\hline $\mathbf{1 0 0} \boldsymbol{\mu l}$ & $93,1 \pm 1,3$ & $98,31 \pm 0,84$ \\
\hline $\mathbf{2 5 0} \boldsymbol{\mu l}$ & $92,2 \pm 0,94$ & $98,96 \pm 0,79$ \\
\hline
\end{tabular}

Current study demonstrated that Helichyrsum has high DPPH radical scavenging activity except for $10 \mu 1$ concentration. Also, this study showed that Helichrysum armenium subsp. araxinum has highest ABTS radical scavenging activity in all of concentrations studied.

Table 6. Fe Chelating activity of Helichrysum armenium subsp. araxinum

\begin{tabular}{|c|c|}
\hline Concentrations & Fe-Chelating \% \\
\hline $\mathbf{1 0 0} \boldsymbol{\mu l}$ & $93,2 \pm 1,14$ \\
\hline $\mathbf{5 0 0} \boldsymbol{\mu l}$ & $38,1 \pm 0,57$ \\
\hline
\end{tabular}

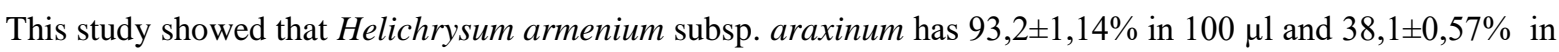
$500 \mu \mathrm{l} \mathrm{Fe}$-chelating activity.

\section{Conclusions and discussion}

It was found that Helichrysum armenium subsp. araxinum has highest saturated fatty acid content (69.06\%).

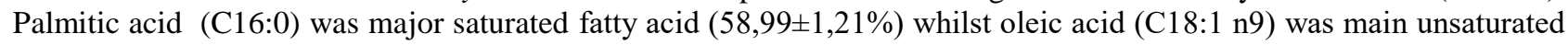
fatty acid content of Helichrysum armenium subsp. araxinum $(9,20 \pm 0,84 \%)$. Dilika et al. [25] indicated that Helichrysum 
has linoleic and oleic acids contents. Also, Powell et al. [26] indicated that Helichrysum has usual palmitic, stearic, oleic, and linoleic acids. It was found that the lipid soluble vitamin contents of Helichrysum armenium subsp. araxinum were trace or lowest in the present study. In addition, present study showed that stigmasterol content was 79,4 $\pm 1,17 \mu \mathrm{g} / \mathrm{g}$ and $\beta$-sitosterol was $29,2 \pm 0,87 \mu \mathrm{g} / \mathrm{g}$, whilst ergosterol content was $0,5 \pm 0,01 \mu \mathrm{g} / \mathrm{g}$. Different studies showed that Helichrysum has $\beta$-sitosterol and stigmasterol compounds [27]. As far as we know this is the first report for lipid soluble vitamin contents of Helichrysum armenium subsp. araxinum.

Present study showed that Helichrysum armenium subsp. araxinum has highest naringenin content $(1156,8 \pm 3,57$ $\mu \mathrm{g} / \mathrm{g})$. Also, this study found that rutin $(396,24 \pm 2,57 \mu \mathrm{g} / \mathrm{g})$ and catechin $(181,8 \pm 2,47)$ contents of Helichrysum armenium subsp. araxinum were high. Pljevljakusic et al. [28] showed that Helichrysum has flavanones naringenin (4) and naringenin-5-O-glucoside are the dominant compounds in sandy everlasting. Also, Kolayli et al. [29] found that Helichyrsum has rutin, catechin and quercetin. However Albayrak et al. [14] suggested that Helichrysum doesn't contain rutin. They indicated that chlorogenic acid, apigenin-7-glucoside and apigenin contents of Helychrysum were highest [14]. It was demonstrated that apigenin, naringenin, apigenin-7-O-glucoside and naringenin-O-hexosides were major constituents study done Gradinaru et al. [30]. The literatures demonstrated that Helichrysum has apigenin, isorhamnetin, quercetin, myricetin, naringenin and kaempherol [31,11]. On the other hand, present study showed that Helichrysum has high vanilic acid $(213,2 \pm 2,32 \mu \mathrm{g} / \mathrm{g})$, caffeic acid $(151,6 \pm 1,27 \mu \mathrm{g} / \mathrm{g})$ and ferulic acid $(117,94 \pm 1,26 \mu \mathrm{g} / \mathrm{g})$. Also, it was found that Helichrysum armenium subsp. araxinum has cinnamic acid $(7,1 \pm 0,84 \mu \mathrm{g} / \mathrm{g})$ and rosmarinic acid $(26,6 \pm 0,87$ $\mu \mathrm{g} / \mathrm{g}$ ). Kolayli et al. [29] found that Helichrysum has vanilic acid, caffeic acid, cinnamic acid, chlorogenic acid, syringic acid, coumaric acid, ferulic acid, benozic acid and gallic acid. Also, Bryksa-Godzisz et al. [31] showed that high chlorogenic and ferulic acid contents. Furthermore, another study showed that Helichrysum has caffeic acid, chlorogenic acid and quinic acid [32].

This study showed that DPPH scaveging activity of Helichrysum armenium subsp. araxinum was high (apart from $10 \mu \mathrm{l}$ ) and Helichrysum armenium subsp. araxinum has highest ABTS radical scavenging acitivities in all of concentrations studied. Albayrak et al. [14] indicated that all the extracts of Helichrysum including Helichrysum armenium displayed an rising in free radical scavenging capacity. Aiyegoro and Okoh [8] concluded that Helichrysum has potently active DPPH and ABTS scavenging. Also, Gouveia and Castillo [33] demonstrated that all of Helichrysum extracts represented scavenging activity against DPPH and ABTS. Similarly, Aiyegoro and Okoho [34] indicated that Helichrysum extracts displayed scavenging activity against all radicals including DPPH and ABTS tested. Also, it was suggested that Helichrysum taxa represented strong free radical-scavenging activity [35,36]. On the other hand, this study

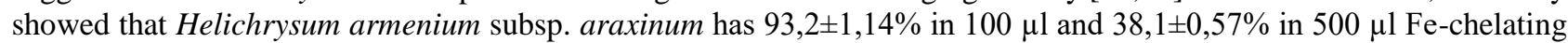
capacity. Haddouchi et al. [37] found that Helichrysum has highest ferric-ion chelating capacity. Similarly, the results of study done by Aiyegoro and Okoho [30] suggested that Helichrysum has Fe-chelating reducing power.

Present study demonstrated that saturated fatty acid composition of Helychrysum armenium subsp. araxinum highly especially palmitic acid and it has lowest lipid soluble vitamin contents. However, it was showed that Helychrysum armenium subsp. araxinum has highest naringin content and high vanilic acid, caffeic acid and ferulic acids. Moreover, current study suggested that Helichrysum armenium subsp. araxinum has strong antioxidant capacity.

(Bu çalışmanın bir bölümü 8-10 Mart 2019 tarihlerinde 6. Uluslararası Matematik, Mühendislik, Fen ve Sağlık Bilimleri Kongresinde sözlü bildiri olarak sunulmuş ve özet kitapçığında basılmıştır.)

\section{References}

[1] Perrini, R., Morone-Fortunato, I., Lorusso, E. \& Avato, P. (2009). Glands, essential oils and in vitro establishment of Helichrysum italicum (Roth) G. Don ssp. microphyllum (Willd.) Nyman. Ind. Crops Prod. 29, 395-403.

[2] Baytop, T. (1997). Türkçe Bitki Adları Sözlüğü, Türk Dil Kurumu Yayınları, Ankara.

[3] Yapar, Y. \& Behçet, L. (2018). The flora of Hiro Plateau (Adakl1-Bingöl/ Turkey) and its surroundings. Biological Diversity and Conservation 11(3), 126-140.

[4] Baykal, H., Atamov, V. \& Yüksek, T. (2018). Flora of Tunca Valley Natural Park and environs (Ardeşen-Rize/Turkey). Biological Diversity and Conservation, 11(2), 9-24.

[5] Yüce Babacan, E., Vitek, E. \& Çakılcığlu, U. (2017). Contributions to the Flora of Tunceli (Turkey). International Journal of Nature and Life Sciences, 1(2), 39-66.

[6] Keser, A.M. \& Özgökçe, F. (2019). The Flora of Karz (Garez) Mountain (Tatvan, Bitlis/ Turkey). Biological Diversity and Conservation, 12(2), 78-91.

[7] Davis, P.H. (1985). Flora of Turkey and the East Aegean Islands. Vol. 1-9. Edinburgh: Edinburgh University.

[8] Aiyegoro, O. \& Okoh, A.I. (2010). Preliminary phytochemical screening and In vitro antioxidant activities of the aqueous extract of Helychrysum longifolium DC. BMC Complementary and Alternative Medicine, 21.

[9] Maksimovic, S., Tadic, V., Skala, D. \& Zizovic, I. (2017). Separation of phytochemicals from Helichrysum italicum: An analysis of different isolation techniques and biological activity of prepared extracts. Phytochemistry, 138, 9-28.

[10] Aslan, M., Orhan, D.D., Orhan, N., Sezik, E. \& Yesilada, E., (2007). A study of antidiabetic and antioxidant effects of Helichrysum graveolens capitulums in streptozotocininduced diabetic rats. J. Med. Food 10, 396-400. 
[11] Suzgec-Selcuk, S. \& Birteksoz, A.S. (2011). Flavonoids of Helichrysum chasmolycicum and its antioxidant and antimicrobial activities. South African Journal of Botany 77, 170-174.

[12] Valero, M.S. \& Lope, V. (2017). Everlasting flower (Helichrysum stoechas Moench) as a potential source of bioactive molecules with antiproliferative, antioxidant, antidiabetic and neuroprotective properties. Industirla Crops \&Products, 108, 295-302.

[13] Gouveia, S.C. \& Castilho, P.C. (2010). Characterization of phenolic compounds in Helichrysum melaleucum by highperformance liquid chromatography with on-line ultraviolet and mass spectrometry detection. Rapid Commun. Mass Spectrom.; 24: 1851-1868.

[14] Albayrak, S., Aksoy, A., Sagdic, O. \& Hamzaoglu, E. (2010). Compositions, antioxidant and antimicrobial activities of Helichrysum (Asteraceae) species collected from Turkey. Food Chemistry 119, 114-122.

[15] Hara A. \& Radin N.S. (1978). Lipid extraction of tissues with a low-toxicity solvent. Anal. Biochem. 90 (1): $420-426$.

[16] Christie, W.W. (1990). Gas Chromatography and lipids. The oily press: Glaskow, UK, pp. 573-577.

[17] Sanchez-Machado D.I., Lopez-Hernandez J. \& Paseiro-Losado P. (2002). High-performance liquid chromatographic determination of a-tocopherol in macroalgae. Journal of Chromatography A, 976 (1): 277-284.

[18] L'opez-Cervantes, J., S'Anchez-Machado, D.I. \& R'ios-V'Azquez, N.J. (2006). High-performance liquid chromatography method for the simultaneous quantification of retinol, $\alpha$-tocopherol, and cholesterol in shrimp waste hydrolysate. Journal of Chromatography A 1105: 135-139.

[19] Zu, Y.G., Li, C.Y., Fu, Y.J. \& Zhao, C.J. (2006). Simultaneous determination of catechin, rutin, quercetin kaempferol and isorhamnetin in the extract of sea buckthorn (Hippophae rhamnoides L.) leaves by RP-HPLC with DAD. Journal of Pharmaceutical and Biomedical Analysis 41: 714-719.

[20] Liyana-Pathıranan, C.M. \& Shahidi, F. (2005). Antioxidant activity of commercial soft and hard wheat (Triticum aestivum L.) as affected by gastric $\mathrm{pH}$ conditions. Journal of Agricultural and Food Chemistry 53: 3-2440.

[21] Ree, R., Pellegrini, N., Proteggente, A., Pannala, A., Yang, M. \& Rice-Evans, C. (1999). Free Radic. Biol. Med. 26, 1231-1237.

[22] Skotti, E., Anastasaki, E., Kanello, G., Polissiou, M. \& Tarantilis, P.A. (2014). Total phenolic content, antioxidant activity and toxicity of aqueous extracts from selected Greek medicinal and aromatic plants. Industrial Crops and Products 53, 46-54.

[23] Dinis, T.C.P, Madeira, V.M.C. \& Almeida, M.L.M. (1994). Action of phenolic derivates (acetoaminophen, salycilate and 5-aminosalycilate) as inhibitors of membrane lipid peroxidation and as peroxyl radical scavengers. Arch. Biochem. Biophys. 315: 161-169.

[24] Kizilpinar Temizer, I., Guder, A. \& Celemli, O.G. (2017). Botanical origin and antioxidant activities of propolis from the Irano-Turanian region. Istanbul J Pharm 47 (3): 107-111.

[25] Dilika, F., Bremner, P.D. \& Meyer, J.J.M. (2000). Antibacterial activity of linoleic and oleic acids isolated from Helichrysum pedunculatum: a plant used during circumcision rites. Fitoterapia 71, 450- 452.

[26] Powell, R.G., Smith, C.R. \& Wolff, I.A. (1965). Helichrysum see oil. I. Separation and characterization of individual acid. Journal of the American Oil Chemists' Society 42(3):165-169.

[27] Eshbakova, K.A. \& Aisa, H.A. (2009). Components of Helichrysum arenarium. Chem. Nat. Comp. 45, 929-930. doi: 10.1007/s10600-010-9462-3.

[28. Pljevljakušic, D., Bigovi, D., Jankovi, T., Jelaci, S. \& Šavikin, K. (2018). Sandy' Everlasting (Helichrysum arenarium (L.) Moench): Botanical, Chemical and Biological Properties. Front. Plant Sci. 9:1123.

[29. Kolayli, S., Sahin, H., Ulusoy, E. \& Tarhan, O. (2010). Phenolic Composition and Antioxidant Capacities of Helichrysum plicatum. Hacettepe J. Biol. \& Chem., 38 (4) 269-276.

[30] Gradinaru, A.C., Silion, M., Trifan, A., Miron, A. \& Aprotosoaie, A.C. (2014). Helichrysum arenarium subsp. arenarium: phenolic composition and antibacterial activity against lower respiratory tract pathogens. Nat Prod Res., 28(22):2076-2080.

[31] Bryksa-Godzisz, M., Weglarz, Z. \& Przybyl, J. (2006). Phenolic compounds in yellow everlasting (Helichrysum arenarium (L.) Moench) growing wild in the middle part of the Bug river valley. Herba Polonica, 52 (4), 26-31.

[32] Mari, A., Napolitano, A., Masullo, M., Pizza, C. \& Piacente, S. (2014). Identification and quantitative determination of the polar constituents in Helichrysum italicum flowers and derived food supplements. Journal of Pharmaceutical and Biomedical Analysis 96, 249-255.

[33] Gouveia, S. \& Castillo, P.C. (2012). Helichrysum monizii Lowe: Phenolic Composition and Antioxidant Potential. Phytochemical Analysis, 23, 72-83.

[34] Aiyegoro, O.A. \& Okoh, A.I. (2009). Phytochemical Screening and Polyphenolic Antioxidant Activity of Aqueous Crude Leaf Extract of Helichrysum pedunculatum. Int. J. Mol. Sci., 10, 4990-5001.

[35] Ozkan, G., Sagdic, O. \& Ozcelik, H. (2004). Some Turkish endemic herb extracts as antibacterial and antioxidant agents. In Fourth international congress environmental micropaleontology, microbiology and meiobenthology (pp. 151- 154). Isparta, Turkey

[36] Albayrak, S., Sagdic, O., Aksoy, A. \& Hamzaoglu, H. (2008). Antimicrobial and antioxidant activities of Helichrysum species from the Mediterranean region of Turkey. Asian Journal of Chemistry, 20, 3143-3152.

[37] Haddouchi, F., Chaouche, T.M., Ksouri, R., Medini, F., Sekkal, F.Z. \& Benmansour, A. (2014). Antioxidant activity profiling by spectrophotometric methods of aqueous methanolic extracts of Helichrysum stoechas subsp. rupestre and Phagnalon saxatile subsp. saxatile. Chinese Journal of Natural Medicines, 12(6): 0415-0422. 